\title{
Exploration of gene variations in the transcytosis system as a policy proposal for the personalized therapy in type 2 diabetes mellitus
}

\author{
Luis J. Flores-Alvarado ${ }^{1}$ José R. Villafán-Bernal $^{2}$, Carlos E. Cabrera-Pivaral ${ }^{3}$, Carlos J. Castro-Juárez ${ }^{4}$, and Sergio A. Ramirez-Garcia ${ }^{4 *}$ \\ ${ }^{1}$ Biochemistry Laboratory, Health Sciences University Center, Universidad de Guadalajara, Mexico \\ ${ }^{2}$ CONACYT Cathedratic at Division of Surgery, Universidad Autónoma de Aguascalientes, Mexico \\ ${ }^{3}$ Research Center for Social Development, Health Sciences University Center, Universidad de Guadalajara, Mexico \\ ${ }^{4}$ Institute of Public Health Research,Universidad de la Sierra Sur, Oaxaca, Mexico
}

\begin{abstract}
It is important for both the clinical researcher and physician to explore new personalized treatment options for better care of the diabetic patient. The search for genetic or genomic markers in order to predict complications of disease, progression as well as to evaluate the therapeutic response to drugs and the presentation of adverse effects is an area to be explored, considering the high costs that represent the attention of diabetics to hospitals from the public sector. Other reasons are that type 2 diabetes mellitus (T2D) patients develop complications related with the progression of the disease, as well as, adverse and side effects resulting from drug interactions [1,2].
\end{abstract}

The gene system of transcytosis, integrated by LRP2, AMN, CUBN, ARH, AMN and CUBN, might be important for the treatment and monitoring of chronic complications of diabetics, as well as for drug interactions, since they mediate the reuptake of vitamins such as B complex, folic acid and lipoproteins, which are closely related to the progression of diabetes. That is why polymorphisms in those genes could be targets of personalized medicine, to improve the quality of health care.
T2D commonly presents deficiency of vitamin B complex, associated with the long-term consumption of metformin. The consequences of this deficiency are increased cardiovascular risk, renal damage and higher risk of peripheral neuropathy and senile dementia $[1,2]$. Additionally, the chronic consumption of statins for the control of hypercholesterolemia and cardiovascular risk results in secondary dyslipidemia myocytes inflammation $[1,2]$.

The common element that might explain the previously described complications and side effects in T2D diabetic patients is an axis of genes that encode for the system of transcytosis in the cellular membranes from small intestine, kidney, liver, striated muscle, and other tissues. The components of this transcytosis system are LRP2, AMN, CUBN, ARH, Dab2, GIPC, NHE3, ClC5, FcRn and NaPi-IIa, which mediate the reuptake of $\mathrm{B}$ complex vitamins, including folic acid among other molecules [3-10].

The clinical effect of these genes might be seen in the development of different diseases or clinical conditions (Table 1). Mutations in LRP2 have been associated with diabetes, aminoglucosides response, DonnaiBarrow syndrome (DBS), Facio-oculo-acoustic-renal syndrome (FOAR) and Alzheimer's disease. While mutations in AMN and CUB occur with megaloblastic anemia plus albuminuria. CUBallelic variants are related to the progression of renal damage and $A R H$ variations are associated with hypercholesterolemia [3-10]. NHE3 mutations show association with congenital sodium diarrhea, whereas $\mathrm{ClC} 5$ gene is related to renal failure or Dent disease. $\mathrm{ClC5}, \mathrm{FcRn}, \mathrm{NaPi}$-IIIa gene are related with metabolic renal disease. DAB2, GIPC has an uncertain meaning in human pathology, but their pathogenic effect must be explored [11-25].

Considering the interaction between these genes, it would be very useful to analyze the relationship between polymorphisms of single base changes (SNP) of these genes, or the blocks of haplotypes and haplogroups that can be constructed with sets of SNP in T2D patients. Specially, the relationship of such variants with the development of peripheral neuropathy and the appropriate metformin doses. Another field of research is to explore the relationship between the response to statin therapy and the development of myocyte inflammation. The results of this genetic exploration might be translated into predictive markers to prevent complications associated with the commonly used drugs in $\mathrm{T} 2 \mathrm{D}$, allowing a better attention to the patient. These and other personalized medicine protocols should be included by many governments, since they would improve the costs of health care, especially since these genes are directly responsible for renal, neurological and vascular damage, as has been demonstrated in genetic diseases, animal and experimental models.

Correspondence to: Sergio Alberto Ramirez-Garcia, MD, MSc. PhD., Institute of Public Health Research, Universidad de la Sierra Sur. Oaxaca System of State Universities. Guillermo Rojas Mijangos S/N Ciudad Universitaria, Miahuatlán de Porfirio Diaz, Oaxaca, México

Key words: cubilin, diabetes, hypercholesterolemia, megalin

Received: February 28, 2017; Accepted: March 28, 2017; Published: March 31, 2017 


\begin{tabular}{|c|c|c|c|}
\hline Gene & Protein & SNP or pathogenicmutation & Reference \\
\hline LRP2 & Megalin & $\begin{array}{l}\text { rs133980 (associated with hypertension), } \\
\text { rs2544390 (associated with gout and alcohol drinking) } \\
\text { rs1050700 (associated with glomerular filtration rate) } \\
\text { rs3755166, rs2075252, rs4668123 (associated with central adiposity), } \\
\text { rs2075252 and haplotype GA of rs4667591/ rs2075252 (associated with bone mineral density), } \\
\text { rs3755166 (associated with Alzheimer's disease } \\
\text { p.H498Q (associated with type } 2 \text { diabetes mellitus) } \\
\text { c.+193826T/C (associated with hypercholesterolemia) }\end{array}$ & [3-4] \\
\hline CUB & Cubilin & $\begin{array}{l}\text { rs1801239/p.I2984V(associated with diabetic nephropathy and albuminuria) } \\
\text { rs1801240/ p.G3002E (associated with diabetic nephropathy and albuminuria) } \\
\text { p.L2153F (associated with albuminuria) } \\
\text { p.I2984V (associated with diabetic nephropathy) } \\
\text { p.Q3002G (associated with diabetic nephropathy) } \\
\text { rs7918972 (associated with proteinuria) }\end{array}$ & {$[5,8]$} \\
\hline$A M N$ & Amnionless & 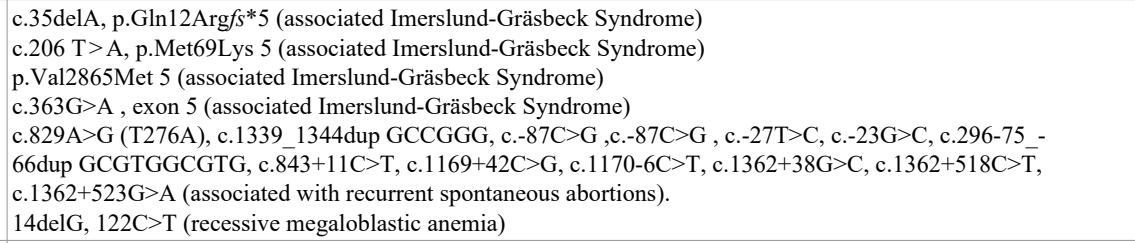 & {$[7,12,13]$} \\
\hline $\begin{array}{l}\text { ARHor } \\
\text { LDLRAP1 }\end{array}$ & $\begin{array}{l}\text { Low density lipoprotein } \\
\text { receptor adaptor } \\
\text { protein } 1\end{array}$ & $\begin{array}{l}\text { p.T56M, del 1.6kb exon } 4 \text { (recessive hypercholesterolemia). } \\
\text { p.P202S, p.P202H, p.R238Trp (determinants of plasma cholesterol levels) }\end{array}$ & [14-16] \\
\hline$D A B 2$ & Clathrinadaptorprotein & rs148700350, rs200879578, rs200879578, rs200754366 & $\begin{array}{l}\text { Gene Bank, Not yet } \\
\text { studied, Uncertain } \\
\text { significance }\end{array}$ \\
\hline GIPC & $\begin{array}{l}\text { PDZ domain containing } \\
\text { family member } 1\end{array}$ & rs 770458112, rs764183065, rs369693566, rs373945556, rs775587781, rs770090326, rs752071186 & $\begin{array}{l}\text { Gene Bank, Not yet } \\
\text { studied, Uncertain } \\
\text { significance }\end{array}$ \\
\hline $\begin{array}{l}\text { SLC9A3 or } \\
\text { NHE3 }\end{array}$ & $\begin{array}{l}\text { Solute carrier family } 9 \\
\text { member A3 }\end{array}$ & 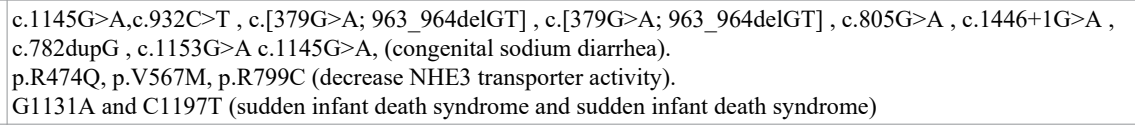 & {$[17-19]$} \\
\hline CLCN5 o CLC5 & $\begin{array}{l}\text { Chloridevoltage- } \\
\text { gatedchannel } 5\end{array}$ & p.T657S, p.R345W and p.Q629X, insertion in codon $650 \mathrm{Alu}$ (Dent disease) & {$[20-21]$} \\
\hline FCGRTorFcRn & $\begin{array}{l}\text { Fc fragment of IgG } \\
\text { receptor and transporter }\end{array}$ & VNTR of promoter region (Response to cetuximab) & [22] \\
\hline $\begin{array}{l}\text { SLC34A1 } \\
\text { or NaPi-IIa }\end{array}$ & $\begin{array}{l}\text { Solute carrier family } 34 \\
\text { member } 1\end{array}$ & $\begin{array}{l}\text { c.1484G }>\text { A, p.R95H (hypophosphatemia and nephrocalcinosis). } \\
\text { 91del7, p.A133V and p.H568Y (calcium nephrolithiasis with renal phosphate leak). } \\
\text { p.R215W, p.C336G, p.V498E, p.W488R, IVS6(+1)G }>\text { A, IVS9(+3_6)del, IVS12(+1)G }>\text { A (associated with } \\
\text { Idiopathic Infantile Hypercalcemia) }\end{array}$ & [23-25] \\
\hline
\end{tabular}

Table 1. Genotype of the of the endocytosis system

\section{References}

1. Rosales RC, López JJ, Núñez NY, González AE, Ramirez-Garcia SA (2010) Type 2 diabetes nephropathy: a thresholds complex trait and chromosomal morbid map. Rev Med Inst Mex Seguro Social 48: 521-530. [Crossref]

2. Ramirez-Garcia SA, Cabrera CE, Huacuja L, Flores LJ, Pérez G, et al. (2013) Implications in primary health care of medical genetics and genomic in type 2 diabetes mellitus. Rev Med Inst Mex Seguro Social 51: e6-e26. [Crossref]

3. Ruiz P, Ramirez-Garcia SA, Cruz J, Cabrera EC (2014) Insights in the Postgenomic Era of the Folates, Vitamin B-12, Selenium and Public Policy in Health. Vitam Miner3: 124.

4. Carrillo C, González M, Ramirez-Garcia SA (2009) Detección molecular de una variante de secuencia del gen que codifica para megalina y el desarrollo de insuficiencia renal causada por diabetes mellitus tipo 2. Bioquimia34: 59 .

5. Flores LJ, Ramirez-Garcia SA, Ferman PD, Daválos NO, Chavéz C, et al (2014) Molecular heterogeneity of type 2 diabetes mellitus in mexican population and its impact of the public health on policies in primary care. Med Chem 4:791-790.

6. Kur E1, Mecklenburg N, Cabrera RM, Willnow TE, Hammes A (2014) LRP2 mediates folate uptake in the developing neural tube. J Cell Sci 127: 2261-2268. [Crossref]

7. Montgomery E, Sayer JA, Baines LA, Hynes AM, Vega V, et al (2015)Nove compound heterozygous mutations in AMN cause Imerslund-Gräsbeck syndrome in two half-sisters: a case report. BMC Med Genet 16:35. [Crossref]

8. Carrillo C, González M, Godínez S (2007) Detección molecular de variantes de secuencia del gen que codifica para cubilina y el desarrollo de insuficiencia renal causada por diabetes mellitus tipo 2. Bioquimia 32: 73.

9. Reznichenko A, Snieder H, van den Born J, de Borst MH, Damman J, et al. (2012) CUBN as a novel locus for end-stage renal disease: insights from renal transplantation. PLoS One 7: e36512. [Crossref]

10. De S, Kuwahara S, Saito A (2014) The Endocytic Receptor megalin and its associated proteins in proximal tubule epithelial cells. Membranes (Basel) 4: 333-355. [Crossref]

11. Oliva- PF, Siqueiros JM, Vázquez JR, Saruwatari G, Carnevale A (2013) Genomic medicine in public health policies: a perspective of Mexican biomedical researchers. Salud Publica Mex55: 16-25. [Crossref]

12. Kaare M, Painter JN, Ulander VM, Kaaja R, Aittomäki K (2006) Variations of the Amnionless gene in recurrent spontaneous abortions. Mol Hum Reprod 12: 25-29. [Crossref]

13. Tanner SM, Aminoff M, Wright FA, Liyanarachchi S, Kuronen M, et al. (2003) Amnionless, essential for mouse gastrulation, is mutated in recessive hereditary megaloblastic anemia. Nat Genet33:426-429. [Crossref]

14. Harada K, Miyamoto Y, Morisaki H, Ohta N, Yamanaka I, et al. (2010) A nove Thr56Met mutation of the autosomal recessive hypercholesterolemia gene associated with hypercholesterolemia. $J$ Atheroscler Thromb 17: 131-140. [Crossref]

15. Quagliarini F, Vallvé JC, Campagna F, Alvaro A, Fuentes-Jimenez FJ, et al. (2007) Autosomal recessive hypercholesterolemia in Spanish kindred due to a large deletion in the ARH gene. Mol Genet Metab92:243-248. [Crossref]

16. Hubacek JA, Hyatt T (2004) ARH missense polymorphisms and plasma cholesterol levels. Clin Chem Lab Med 42: 989-990. [Crossref] 
17. Janecke AR, Heinz-Erian P, Yin J, Petersen BS, Franke A, et al. (2015) Reduced sodium/proton exchanger NHE3 activity causes congenital sodium diarrhea. Hum $\mathrm{Mol}$ Genet24:6614-6623. [Crossref]

18. Zhu XC, Sarker R, Horton JR, Chakraborty M, ChenTE, et al (2015) Nonsynonymous single nucleotide polymorphisms of NHE3 differentially decrease NHE3 transporter activity. Am J Physiol Cell Physiol308:C758-766. [Crossref]

19. Studer J, Bartsch C, Haas C (2014) Sodium/proton exchanger 3 (NHE3) and sudden infant death syndrome (SIDS). Int J Legal Med128: 939-943. [Crossref]

20. Tang X, Brown MR, Cogal AG, Gauvin D, Harris PC, et al. (2016) Functional and transport analyses of CLCN5 genetic changes identified in Dent disease patients. Physiol Rep4: e12776. [Crossref]

21. Claverie-Martin F, González-Acosta H, Flores C, Antón-Gamero M, García-Nieto V (2003) De novo insertion of an Alu sequence in the coding region of the CLCN5 gene results in Dent's disease. Hum Genet 113: 480-485. [Crossref]
22. Passot C, Azzopardi N, Renault S, Baroukh N, Arnoult C, et al. (2013) Influence of FCGRT gene polymorphisms on pharmacokinetics of therapeutic antibodies. MAbs5: 614-619. [Crossref]

23. Rajagopal A, Braslavsky D, Lu JT, Kleppe S, Clément F, et al. (2014) Exome sequencing identifies a novel homozygous mutation in the phosphate transporter SLC34A1 in hypophosphatemia and nephrocalcinosis.J Clin Endocrinol Metab99:E2451-E2456. [Crossref]

24. Lapointe JY, Tessier J, Paquette Y, Wallendorff B, Coady MJ, et al. (2006) NPT2 gene variation in calcium nephrolithiasis with renal phosphate leak. Kidney Int 69 2261-2267. [Crossref]

25. Schlingmann KP, Ruminska J, Kaufmann M, Dursun I, Patti M, et al. (2016) AutosomalRecessive Mutations in SLC34A1 Encoding Sodium-Phosphate Cotransporter 2A Cause Idiopathic Infantile Hypercalcemia. J Am Soc Nephrol27: 604-614. [Crossref]

Copyright: (C2017 Flores-Alvarado LJ. This is an open-access article distributed under the terms of the Creative Commons Attribution License, which permits unrestricted use, distribution, and reproduction in any medium, provided the original author and source are credited. 